\title{
Isolation and Screening of Amylolytic Filamentous Fungi
}

\section{${ }^{1 *}$ IBATSAM KHOKHAR, ${ }^{2}$ IRUM MUKHTAR, ${ }^{3}$ SOBIA MUSHTAQ}

\author{
${ }^{1,2,3}$ First Fungal Culture Bank of the Pakistan, Institute of Plant Pathology, \\ University of the Punjab, Lahore Pakistan \\ *ibatsamk@yahoo.com
}

\begin{abstract}
Filamentous fungi are important due to their high enzymes production potential. Many enzymes produced by fungi have related to biotechnological applications in several industrial sectors. The purpose of this study was to isolate filamentous fungi from different sources and to screen for amylases production potential. Fifteen fungal isolates of three genera, Aspergilus, Penicillium and Trichoderma were examined for their ability to produce amylase. All isolates exhibited enzymatic potential. Penicillium granulatum (FCBP1080), Aspergillus raperi (FCBP1007) and Aspergillus speluneus (FCBP1128) were hyper active in starch medium and showed the increased growth in starch medium as compare to control. This study contributes to catalogue local fungal isolated in Pakistan, and provides additional information to support future research about the industrial enzymes potential of these microorganisms for and, eventually, also secondary metabolites with antimicrobial or anti-parasitic activities. @ JASEM.
\end{abstract}

Key words: amylase, fungi, Penicillium, Aspergillus, enzymes

In last two decade potential of using microorganisms as biotechnological sources of industrially relevant enzymes has stimulated interest in the exploration of extracellular enzymatic activity in several microorganisms (Akpan et al., 1999; Pandey et al., 2000 and Abu et al., 2005). Amylases are important enzymes employed in the starch processing industries for the hydrolysis of polysaccharides such as starch into simple sugar constituents (Akpan et al., 1999; Mitchell \& Lonsane, 1990 and Pederson \& Nielsen, 2000) by degrading 1-4 linkage of starch. Besides their use in starch saccaharification, they also find potential application in a number of industrial processes such as in food, baking, brewing, detergent, textile and paper industries. With the advent of new frontiers in biotechnology, the spectrum of amylase application has expanded into many other fields, such as clinical, medical and analytical chemistry (Pandey et al., 2000).

Although amylases can be obtained from several sources, such as plants and animals, the enzymes from microbial sources generally meet industrial demand (Pandey et al., 2000). Microbial amylases have successfully replaced chemical hydrolysis of starch in starch processing industries. The use of starch degrading enzymes was infact the first largescale application of microbial enzymes in the food industry (Bennett, 1998; Deker, 2003; Lin et al., 1997 and Pandey et al., 2000). Amylase production has been reported from several fungi, yeasts, bacteria and actinomycetes though fungal and bacterial sources are predominant with potential industrial

*Corresponding author: *ibatsamk@yahoo.com applications (Pandey et al., 2006 and Prabakaran et al., 2009) for which, amount to billions of dollars of revenue annually (Sasi et al ., 2010). Fungi have high secretion capacity and are effective hosts for the production of foreign proteins (Tsukagoshi et al., 2001). Filamentous fungi are important organisms for production of useful enzymes and biological active secondary metabolites. These fungi produce high levels of polysaccharide degrading enzymes and are frequently used for the production of industrial enzymes.

Studies on fungal amylase especially in the developing countries have concentrated mainly on Rhizopus sp., and Aspergillus spp., probably because of the ubiquitous nature and non fastidious nutritional requirements of these organisms (Abe et al., 1988). But still there is a need for explore new fungal isolates for amylases activity to fulfill the industrial demand. Therefore, the present investigation deals with the isolation and screening of local amylolytic fungi from different sources, for future investigation and industrial processes.

\section{MATERIAL AND METHODS}

Isolation of Microorganism: Samples were collected from various locations and sources for fungal isolation. Dilution plate method and direct plat method were used for the isolation of fungal isolates (Table. 1).

Screening for Amylase Producing Fungi: The screening procedure for a-amylase was based on a 
plate culture method which uses soluble starch $(2 \%)$ as the sole carbon source. The screening plate medium contained $1.0 \mathrm{~g} \mathrm{NaNO}_{3}, 1.0 \mathrm{~g} \mathrm{~K}_{2} \mathrm{HPO}_{4}, 0.5 \mathrm{~g}$ $\mathrm{MgSO}_{4} .7 \mathrm{H}_{2} \mathrm{O}, 0.01 \mathrm{~g} \mathrm{FeSO}_{4}, 20 \mathrm{~g}$ soluble starch, and $20 \mathrm{~g}$ agar per liter. The initial $\mathrm{pH}$ was adjusted to 6.0. The medium was sterilized by autoclaving at $121{ }^{\circ} \mathrm{C}$ for 15 minutes. Fungi were plated on the agar medium and incubated at $28{ }^{\circ} \mathrm{C}$ for 7 days. Starch degrading activities were detected as clear zones after exposure to iodine solution. Diameters of the clear zones and fungal colonies were evaluated by millimeter ruler.

Table 1. List of Fungi and their sources

\begin{tabular}{|l|l|l|}
\hline FCBP\# & \multicolumn{1}{|c|}{ Fungal isolates } & \multicolumn{1}{c|}{ Sources } \\
\hline 0231 & Aspergillus flavus [Link] & Litchi chinensis, rhizospheric soil \\
\hline 1121 & Aspergillus aculeatus [ [izuka] & Guava rhizospheric soil \\
\hline 0002 & Aspergillus niger [Tiegh] & Garden soil \\
\hline 1128 & Aspergillus speluneus [Raper \& Fennell ] & Maize \\
\hline 1007 & Aspergillus raperi [Stolk \& J.A. Mey.] & Rhizosphere of sponge luffa \\
\hline 1122 & Aspergillus nidulans [(Eidam) G. Winter] & Rhizospheric soil of Citus \\
\hline 0990 & Aspergillus japonicus [Saito] & Shisham seed \\
\hline 1031 & Aspergillus ficuum [Reichardt) Thom \& Currie] & Rhizosphere of Parthenium \\
\hline 1047 & Aspergillus phoenicis [Corda (Thom \& Currie)] & Effluent of textile industry \\
\hline 1124 & Aspergillus nidulans var. dentatus [D.K. Sandhu \& R.S. Sandhu] $]$ & Citus rhizospheric soil \\
\hline 1010 & Penicillium oxalicum [Currie \& Thom] & Rhizosphere of lady finger \\
\hline 1080 & Penicillium granulatum [Bainier] & Apple fruit \\
\hline 0755 & Trichoderma harzianum [Rifai] & Wood \\
\hline 0946 & Trichoderma koningii [Oudem] & Citrus fruit \\
\hline 0944 & Trichoderma viride [Pers] & Textile effluent \\
\hline
\end{tabular}

\section{RESULTS AND DISCUSSIONS}

Amylases are significant enzymes employed in the starch processing industries for the hydrolysis of polysaccharides. Microbial amylases meet industrial demands; a large number of them are available commercially. Several microorganisms can produce amylases enzyme. However, enzymes from fungal and bacterial sources have dominated use in industrial field. In fungal sources, Aspergillus and Penicillium are important.

A total of 15 fungal isolates of Aspergillus, Penicillium and Trichoderma were characterized based on cultural as well as morphological characteristics (Domsch et al. 1980; Pitt, 1979 and Raper \& Fennel 1965). Fungal strains were isolated from different samples with various origins. Fungal isolates were screened for their ability to produce amylase. Screening for amylase production from fungal isolates, were carried out by starch agar plate assay. Amylase activity was determined after flooding the plates with iodine solution $\left(0.2 \% \mathrm{I}_{2} / 2\right.$ $\% \mathrm{KI})$. The ability of starch degrading activities of fungi was assessed in terms of diameter of clear zone (DCZ)/diameter of fungus colony (DFC) ratios. Seven strains showed that the highest ability with 9 $\mathrm{cm}$ clear zone. All fungal isolates showed DCZ/DFC ratio equal to one (Table 2).

As a result of this study, it was determined that all strains have ability to produce amylase. Though the conditions of selected source is favorable for the growth of fungi and better niche for moderate mesophilic fungi but the results with screening of amylases production showed the variability and potentiality among isolated fungi. It was also evident that starch medium effected the fungal growth. Penicillium granulatum (FCBP1080), Aspergillus raperi (FCBP1007) and Aspergillus speluneus (FCBP1128) showed the increased growth in starch medium as compare to control. On the other hand, Aspergillus nidulans (FCBP1124) showed little reduction of growth on starch medium.

It is enumerated from the spectrum of microbial cultures employed for enzyme production in solid state fermentation that all isolates tested gave the highest detectable quantities of starch hydrolysis. These findings are in line with the work conducted by various workers (Omemu et al., 2005; Pandey et al., 2006 and Sasi et al., 2010) where the selection of potent species was made by plate method. However, zonation can not in any way be correlated quantitatively with the amount of enzyme produced. Therefore, the isolation of enzyme producers using starch plates can only be partially selected. So, the selection of more efficient amylolytic strains can be made on biochemical basis (Elander, 1982).

The results show that all isolates possessed a high potential for amylase production. Though the production of these enzymes has been improved significantly by the utilization of hyper-producing strains of fungi as well, efforts are still being done to find newer sources of enzymes. In conclusion, 15 fungal isolates exhibited enzymatic potential for 
industrial uses. Some isolates of Aspergillus (FCBP1031, FCBP1047, and FCBP1128) and Penicillium FCBP1010 also showed hyper growth in starch medium. These amylase producing fungi may also serve better in enzyme industries. We consider that these new isolates may have more potential for industrial uses.

Table2. Screening of amylolytic fungi

\begin{tabular}{|l|c|c|c|c|c|}
\hline \multicolumn{1}{|c|}{ Fungal isolates } & DCZ [cm] & $\begin{array}{c}\text { FCD on starch } \\
\text { agar }[\mathrm{cm}]\end{array}$ & $\begin{array}{c}\text { Hydrolysis activity } \\
\text { index= DCZ/FCD }\end{array}$ & $\begin{array}{c}\text { Colony diameter } \\
\text { on malt agar [cm] }\end{array}$ & $\begin{array}{c}\text { Growth stimulation/ } \\
\text { inhibition= index }\end{array}$ \\
\hline Aspergillus flavus & $9.0 \pm 0.00$ & $9.0 \pm 0.00$ & $1.0 \pm 0.00$ & $7.2 \pm 0.07$ & $1.25 \pm 0.00$ \\
\hline Aspergillus aculeatus & $9.0 \pm 0.00$ & $9.0 \pm 0.00$ & $1.0 \pm 0.00$ & $6.2 \pm 0.06$ & $1.45 \pm 0.00$ \\
\hline Aspergillus niger & $9.0 \pm 0.00$ & $9.0 \pm 0.00$ & $1.0 \pm 0.00$ & $7.6 \pm 0.09$ & $1.18 \pm 0.00$ \\
\hline Aspergillus speluneus & $8.3 \pm 0.17$ & $8.3 \pm 0.17$ & $1.0 \pm 0.02$ & $3.8 \pm 0.09$ & $2.18 \pm 0.04$ \\
\hline Aspergillus raperi & $8.5 \pm 0.12$ & $8.5 \pm 0.12$ & $1.0 \pm 0.03$ & $3.7 \pm 0.09$ & $2.30 \pm 0.03$ \\
\hline Aspergillus nidulans & $6.4 \pm 0.46$ & $6.4 \pm 0.46$ & $1.0 \pm 0.07$ & $6.5 \pm 0.09$ & $0.99 \pm 0.07$ \\
\hline Aspergillus japonicus & $9.0 \pm 0.00$ & $9.0 \pm 0.00$ & $1.0 \pm 0.00$ & $7.5 \pm 0.09$ & $1.20 \pm 0.00$ \\
\hline Aspergillus ficuum & $9.0 \pm 0.00$ & $9.0 \pm 0.00$ & $1.0 \pm 0.00$ & $6.8 \pm 0.15$ & $1.32 \pm 0.00$ \\
\hline Aspergillus phoenicis & $9.0 \pm 0.00$ & $9.0 \pm 0.00$ & $1.0 \pm 0.00$ & $5.8 \pm 0.12$ & $1.55 \pm 0.00$ \\
\hline $\begin{array}{l}\text { Aspergillus nidulans var. } \\
\text { dentatus }\end{array}$ & $9.0 \pm 0.00$ & $9.0 \pm 0.00$ & $1.0 \pm 0.00$ & $8.3 \pm 0.09$ & $1.08 \pm 0.00$ \\
\hline Penicillium oxalicum & $9.0 \pm 0.00$ & $9.0 \pm 0.00$ & $1.0 \pm 0.00$ & $5.8 \pm 0.06$ & $1.55 \pm 0.03$ \\
\hline Penicillium granulatum & $4.9 \pm 0.36$ & $4.9 \pm 0.36$ & $1.0 \pm 0.07$ & $1.9 \pm 0.06$ & $2.60 \pm 0.27$ \\
\hline Trichoderma harzianum & $9.0 \pm 0.0$ & $9.0 \pm 0.0$ & $1.0 \pm 0.00$ & $7.6 \pm 0.07$ & $1.18 \pm 0.00$ \\
\hline Trichoderma koningii & $7.5 \pm 0.12$ & $7.5 \pm 0.12$ & $1.0 \pm 0.02$ & $5.8 \pm 0.06$ & $1.30 \pm 0.02$ \\
\hline
\end{tabular}

$F C D=$ Fungal colony Diameter $; D C Z=$ Diameter of clear $z o n e$.

On the basis of current status of modern biotechnology, amylases are now gaining importance in industrial applications. Food and starch based industries is the major market and thus the demand of aamylases would always be high in these sectors. Therefore new sources of micorganism are needed to complete the industrial enzyme demand in future. It can be concluded that, these new fungal isolates can be industrially exploited for the synthesis of amylase and glucoamylase, and strain improvement studies can be carried out to enhance enzyme production.

\section{REFRENCES}

Abe, J; Bergman, FW; Obeta, K; Hizukuri, S (1988). Production of the raw starch degrading amylase of Aspergillus sp. K-27. Appl Microbiol Biotechnol, 27: 447-450.

Abu, EA; Ado, SA; James, DB (2005). Raw starch degrading amylase production by mixed culture of Aspergillus niger and Saccharomyces cerevisae grown on Sorghum pomace. Afr J Biotechnol, 4(8): 785- 790.

Akpan, I; Bankole, MO; Adesemowo, AM; LatundeDada, GO (1999). Production of amylase by $A$. niger in a cheap solid medium using rice band and agricultural materials. Trop Sci, 39: 77-79.

Bennett, JW (1998). Mycotechnology: the role of fungi in biotechnology. J Biotechnol, 66: 101-107.
Dekker, M (2003). Handbook of Fungal Biotechnology. Dilip K. Arora ed., New York, 600 p.

Domsch, KH; Gans, W; Anderson, TH (1980). Compendium of Soil Fungi. London, New York, Torroute, Sydney, San Francisco: Academic Press. 869p.

Elander, RP (1982). Traditional versus current approaches to the genetic improvement of microbial strains In: Overproduction of Microbial products. (Eds.): V. Krumphanzl, B. Sikyta and Z.Vanek. 353-369.

Lin, LL; Hsu, WH; Chu, WS (1997). A gene encoding for thermophilic Bacillus sp., strain TS23 and its expression in Escherichia coli. J Appl Microbiol, 82: 325-334.

Mitchell, DA; Lonsane, BK (1990). In: General principles of Solid State fermentation, Monogram, ed by Doelle HW, Rolz C. Publication of Oxford London.

Omemu, AM; Akpan I; Bankole, MO; Teniola, OD (2005). Hydrolysis of raw tuber starches by amylase of Aspergillus niger AM07 isolated from the soil. Afr J Biotechnol, 4(1): 19-25.

Pandey, A; Nigamp, VT; Socco, L; Singh, D; Mohan, $R$ (2006). Advances in microbial amylases. Biochem, 31: 35-152. 
Pandey, C; Soccol R; Mitchell, D (2000). New developments in solid state fermentation, Process Biochem, 35: 1153-1169.

Pederson, H; Nielsen, J (2000). The influence of nitrogen sources on the alpha-amylase productivity of Aspergillus oryzae in continuous cultures. Appl Microbiol Biotechnol, 53(3): 278281.

Pitt, JI (1979). The Genus Penicillium and its teleomorphic states Eupenicillium and Talaromyces. London: Academic Press. $634 \mathrm{p}$
Prabakaran, M; Thennarasu, V; Mangala, RA; Bharathidasan, R; Chandrakala, N; Mohan, N (2009). Comparative studies on the enzyme activities of wild and mutant fungal strains isolated from sugarcane field. Indian $\mathbf{J}$ Sci Technol, 2(11): 46-49.

Raper, KB; Fennel, DI (1965). The Genus Aspergillus. Baltimore: Wilkins.

Sasi, A; Kani, M; Panneerselvam, A; Jegadeesh, G; Muthu, K; Kumar, MR (2010). Optimizing the conditions of amylase by an Esturian strain of Aspergillus spp. Afr J Microbiol Res, 4 (8): 581586.

Tsukagoshi, N; Kobayashi, T; Kato, M (2001). Regulation of the amylolytic and hemi-cellulolytic genes in aspergilli. JGMA, 47: 1-19. 